\title{
ANALYSIS OF EDUCATIONAL LEADERSHIP PRINCIPLES BY STUDENT PERCEPTION
}

\author{
Kusmintardjo \\ Department of Educational Management \\ State University of Malang, Indonesia \\ kusmintardjo.fip@um.ac.id
}

\author{
Ahmad Nurabadi \\ Department of Educational Management \\ State University of Malang, Indonesia \\ ahmad.nurabadi.fip@um.ac.id
}

\begin{abstract}
Studies and research on leadership continue to flourish, and from this emerges various leadership approaches and theories. Most of the leadership approaches and theories developed over the past half century have emphasized the characteristics of leaders. As one of the earliest approaches or theories of studying leadership, the traits approach emphasizes the nature or character of leaders such as personality, social, intellectual characters that are thought to have an effect on the effectiveness and success of the organization toward its goals. The results show there are 60 traits or characters that educational leaders should have (according to student perceptions). There are 30 traits or characters that educational leaders should not have. There are ten characteristics or characters of the most preferred educational leaders according to the students' perceptions. There are 23 characteristics or characteristics of educational leaders are the most disliked according to student perceptions.
\end{abstract}

Keywords: nature of leader, perception

\section{INTRODUCTION}

Leadership problems have long been seen as one of the most important factors that determine the success of an organization in achieving its objectives. Leadership is seen as a central point that keeps the balance of other elements of an organization in achieving its goals. It is therefore not surprising that leadership issues have always been a central issue from generation to generation. Studies and research on leadership continue to flourish, and out of this comes a variety of leadership approaches and theories. Most leadership approaches and theories developed over the past half century emphasize more on the characteristics of leaders, and this is done to limit the focus only on the character of leadership, namely nature, behavior, and power [9]. As one of the earliest approaches or theories of studying leadership, the traits approach emphasizes the nature of leaders such as personality, social, intellectual allegedly influencing the effectiveness and success of the organization to achieve its goals.

Likewise, the school or faculty as an educational organization, the success of achieving goals is determined by the effectiveness of existing leadership. The role of educational leaders (principals/deans) in improving the performance of educational institutions has long been recognized as an important factor in educational organizations, particularly their responsibility in improving school learning programs [4]. Some research results indicate that the effectiveness of educational institutions is the result of the actions of effective education leaders [2] [6]

Many theories are trying to identify the characteristics or character of leaders, but so far not many studies that try to identify the nature or character of educational leaders. Thus, it is necessary to have research that focuses on identifying the characteristics or characteristics of educational leaders that effectively support the achievement of educational goals.
Leadership is often defined differently depending on the perspective used. In this case, Stogdill [5] concludes that there are many definitions of leadership that are equal to the number of people who define this concept. The definition of leadership can also be formulated based on the characteristics or attributes attached to a person called a leader. Leadership can also be defined based on the behavior, influence, and patterns of interaction between a leader and the people he leads. However, it should be realized that the debate on the definition of leadership is not only related to who uses the influence but also the type of influence used and what the outcome [9]

The study of leadership usually refers to the development of thought that can be classified into leadership theories. Furthermore, from the leadership theories appear various approaches in its application. One of the earliest approaches to assessing leadership is the traits approach. The nature approach or theory seeks to identify a number of distinctive traits or characters, such as personality, intellectual, and mental and physical, which allegedly influence leadership success. This approach is based on the assumption that there are some people possessing certain traits that others do not possess, and they need to be possessed by a leader. This theory suggests that managerial success is due to the ownership of extraordinary traits of a leader, such as intelligence, personality, and physical characteristics. It further explained that the leader should be smarter, than his followers, but the extreme intelligence differences between the leader and his followers can cause disruption. So is the personality of leaders such as self-confidence, personal integrity can be linked to effective leadership. In this regard, [9] asserts that the earliest leadership theory states that managerial success is due to the extraordinary abilities to have tireless energy, managerial intuition, future views and unbearable persuasive forces. It further explained that many studies of the nature of leaders have been done but this research failed to find the various traits that guarantee leadership success. Failure 
is one of them because the existing study ignores the situation variable as a variable between or moderator. Often the results of this study fail to explain the difference between the characteristics that the leader possesses and the qualities possessed by non-leaders.

At first came hereditary thought that the leadership was born. [7] state the hereditary approach state that the leaders are born and not made - that the leaders do not acquire the abilities, but inherit it. The hereditary approach states that leaders are born not made - that leaders can not gain the ability to lead but inherit it. Then another thought emerged that the leader was made and not made. This opinion states that the leader can be trained or made because in essence, everyone has the potential to be a leader.

With regard to the approach of nature in leadership, there are several opinions relating to the traits that a leader requires. Stogdill [5] suggests that from 15 observations found 5 characteristics of the leader should have: intelligence, scholarship, dependability in exercising responsibilities, activity, and social participation, and socioeconomic status. Then based on more than 10 observational studies it was proposed that a leader should have the following properties: sociability, initiative, persistence, knowing how to get done, self-confidence, alertness to and insight into situation, cooperativeness, popularity, adaptability, and verbal Facility. [3] then compare the qualities that should be to the leader with qualities that should not be the leader. The qualities that should be the leader include: diligent, enterprising, resourceful, strong, courageous, cooperative, confident $/ \mathrm{calm}$, carefree, mature emotions, moral, intelligent, gifted and selfless. While the qualities should not be the leader include: lazy, stubborn, error-free, embarrassed, cowardly, non-retreating, restless, rigid, emotionless, emotionless, resourceless, bored, and fanatical.

Based on some of the above opinions, it is temporary conclusion that the qualities that should be possessed by the leader are as follows: intelligent, contingent, emotional maturity, communication skills, peace of mind, knowledgeable, sociable, confident, Perseverance, good hope, courage, humanity, willingness to accept, able to solve problems, be able to adjust, and so forth.

\section{METHODS}

Quantitative research is broadly divided into two, namely Experimental Research (Experimental Research) and Non-Experimental Research [8]. This study included non-experimental research with a comparative descriptive research design type. [8] mentions, that "descriptive research is research that aims to describe a phenomenon as it is at the time the study was done". In other words describe systematically, factually, and accurately a particular situation, condition or area of interest. Descriptive research may be related to the assessment of attitudes or opinions, can also be an understanding of a particular case, organization or community life. The descriptive design is intended to describe or describe the Nature of Educational Leaders according to Student Perceptions.
Instruments used in this study, namely questionnaires (questionnaires). "Questionnaires are a number of written questions that are used to obtain information from respondents in the sense of reports about his personality, or things he knows" [1]. According to [8] "questionnaire is a list of questions to be filled that will be measured to obtain information about the state/data self, experience, knowledge, attitudes or opinions of respondents". The questionnaire is used by researchers to find out the Analysis of the Nature of Educational Leaders According to Student Perceptions. The study used an open questionnaire, in which case each respondent was given a paper and asked to write down five (5) characteristics of leaders that should be owned by the education leader and five (5) qualities that should not be owned by an educational leader. The properties in question are categorized according to the characteristics of the choice of answers.

\section{RESULT}

Results of Analysis of Properties or Characteristics that Educative Leaders Should Have According to Student Perceptions

Description of data analysis results about the characteristics or characters that should be owned by educational leaders according to student perceptions is depicted in Table 1.

Based on Table 1 it can be explained that there are 60 characteristics or characteristics of educational leaders that educational leaders should have (according to student perceptions). Of the number of qualities, leaders can be classified based on the number or percentage of student choice as follows. There are ten qualities that should be owned by educational leaders (according to student perceptions) chosen by 114 respondents $(100 \%)$ are responsible, wise, honesty, discipline, commitment, caring, human, able to solve problems, one word and deed, And creative. There are 4 characteristics that should be owned by education leader (according to student perception) chosen by 113 respondents $(99,2 \%)$ that is: emotional stability, enthusiasm spirit, open to criticism, and innovative. There are 10 characteristics that should be owned by education leader (according to student perception) chosen by 112 respondents $(98,25 \%)$ that is: fair, inspirational, exemplary, hospitality, assertiveness, nurturing, own integrity, confident, intelligent, and Able to solve the problem. Furthermore, there are 1 characteristics that should be owned by education leader (according to student perception) chosen by 111 respondents $(97,37 \%)$ that are: likes to cooperate. There are 6 characteristics that should be owned by education leader (according to student perception) chosen by 110 respondents $(96,49 \%)$ that is: openness, firmness of stand, patience, able to adjust, respect another opinion, and able to communicate orally. There are 5 characteristics that should be owned by education leader (according to student perception) chosen by 109 respondents $(95,61) \%)$ that is: trust, perseverance, humility, giving priority to other people's interest, and able to make the most appropriate decision. There are 6 characteristics 
that should be owned by education leader (according to student perception) chosen by 108 respondents $(94,74 \%)$ that are: initiative, breadth of view, maturity, confidence, morals, and likes help. There is one trait or character that should be owned by educational leaders according to the perception of 107 students/respondents (93.86\%), namely: the nature of socializing or making friends.

Table 1

Properties or Characteristics that Educative Leaders Should Have According to Student Perceptions

\begin{tabular}{|c|c|c|c|}
\hline No & Properties That Should Have Educational Leaders & Number of Respondents & $\begin{array}{l}\text { Percentage } \\
(\%)\end{array}$ \\
\hline 1 & $\begin{array}{l}\text { Responsible, wise, honest, disciplined, committed, caring, humane, able to solve } \\
\text { problems, one word-one deed, and creative. }\end{array}$ & 114 & 100 \\
\hline 2 & Have emotional stability, enthusiasm, openness to criticism, and innovative. & 113 & 99,2 \\
\hline 3 & $\begin{array}{l}\text { Fair, inspirational, exemplary, hospitality, firmness, nurturing attitude, personal } \\
\text { integrity, confidence, intelligence, and problem-solving. }\end{array}$ & 112 & 98,25 \\
\hline 4 & Likes to work together. & 111 & 97,37 \\
\hline 5 & $\begin{array}{l}\text { Openness, persistence, patience, adaptability, respect for the opinions of others, and } \\
\text { able to communicate verbally. }\end{array}$ & 110 & 96,49 \\
\hline 6 & $\begin{array}{l}\text { Trustfulness, diligence, humility, giving priority to the interests of others (groups) } \\
\text { and being able to make the right decisions. }\end{array}$ & 109 & 95,61 \\
\hline 7 & Having initiative, breadth of view, maturity, confidence, morality, and helpfulness & 108 & 94,74 \\
\hline 8 & Have sociable or friends. & 107 & 93,86 \\
\hline 9 & Simple, and able to maintain interpersonal relationships. & 106 & 92,98 \\
\hline 10 & Charismatic & 105 & 92,11 \\
\hline 11 & Divinity, flexibility, and achievement motivation. & 104 & 91,23 \\
\hline 12 & $\begin{array}{l}\text { Humorists, understand themselves, are able to communicate in writing, and have a } \\
\text { physical freshness. }\end{array}$ & 102 & 89,47 \\
\hline 13 & Sincerity & 101 & 88,6 \\
\hline 14 & Excellent health & 100 & 87,72 \\
\hline 15 & Teaching skills & 96 & 84,21 \\
\hline 16 & Has an extensive educational insight & 82 & 71,93 \\
\hline 15 & Having technical expertise in education. & 65 & 57,02 \\
\hline 16 & Have a good look (dress mode). & 49 & 42,98 \\
\hline 17 & Cute (beautiful and handsome) & 31 & 27,19 \\
\hline
\end{tabular}

There are two qualities that should be owned by educational leaders according to the perception of 106 students/respondents (92.98\%), namely: simplicity, and able to maintain interpersonal relationships. There is one trait that should be owned by education leader according to perception 105 student/respondent $(92,11 \%)$, that is: charismatic. There are three qualities that should be owned by the leader of education according to the perception of 104 students/respondents (91.23\%), namely: piety, flexibility, and achievement motivation. There are four qualities that should be owned by the leader of education according to the perception of 102 students/respondents $(89.47 \%)$, namely: humorous, understand himself, able to communicate in writing, and have physical freshness. There is one trait that should be owned by the leader of education according to the perception of 101 students/respondents (88.60\%), namely: sincerity.

There is one trait that should be owned by the leader of education according to the perception of 100 students/respondents $(87.72 \%)$, namely: excellent health. There is one trait that should be owned by education leader according to perception 96 student/respondent $(84,21 \%)$, that is teaching a skill. There is one trait that should be owned by the leader of education according to the perception 82 students/respondents ( $71.93 \%)$, namely: have a broad educational insight. There is one characteristic that should be owned by education leader according to perception 65 student/respondent $(57,02 \%)$, that is: have the technical expertise of education field. There is one trait that should be owned by education leader according to perception 49 student/respondent $(42,98 \%)$, that is good appearance (dress mode). Next, there is one trait that should be owned by the leader of education according to the perception 31 students/respondents (27.19\%), namely: cute (beautiful/handsome).

\section{Results of Analysis of Properties Or Character Should Not Be Owned by Educational Leaders According to Student Perceptions}

Description of data on the analysis of traits or characteristics that educational leaders should not have according to student perceptions in Table 2. Based on Table 2 it can be explained that there are 30 characteristics or characteristics of educational leaders that should not have the leader of education according to the students' perceptions. Of the number of qualities, leaders can be classified based on the number or percentage of student choice as follows.

There are twenty-three traits that the leader of education should not have perceived by 114 students (100\%) are: arrogant, indifferent, verbiage, lying, discriminatory, egotistical, corrupt, lacking commitment, rigid, slow in making decisions, Lazy, self-centered, cowardly, fearful, pretentious, procrastinating, closed, unpopular, rash, irresponsible, non-innovative, undisciplined, inconsistent and uncreative. Furthermore, there are three traits that should not be owned by the leader of education according to the perception of 113 students (99.12\%), namely: less nimble, stingy, and arrogant. 
Table 2

Properties or Characters that Education Leaders Should not Have According to Student Perceptions

\begin{tabular}{|c|c|c|c|}
\hline No & $\begin{array}{c}\text { Properties That Should Not Be Owned by } \\
\text { Educational Leaders }\end{array}$ & $\begin{array}{c}\text { Number of } \\
\text { Respondents }\end{array}$ & Percentage $(\%)$ \\
\hline 1 & $\begin{array}{l}\text { Flood, indifferent, verbose, lying, discriminative, selfish, corruption, lack of } \\
\text { commitment, rigid, slow in making decisions, lazy, cowardly, timid, self- } \\
\text { righteous, procrastinating, Closed, unpopulated, hasty (reckless), irresponsible, } \\
\text { non-innovative, undisciplined, inconsistent, and uncreative. }\end{array}$ & 114 & 100 \\
\hline 2 & Less dexterous, stingy, and arrogant. & 113 & 99,12 \\
\hline 3 & Fanatic, and promise sale. & 112 & 98,25 \\
\hline 4 & Grumpy. & 111 & 97,37 \\
\hline
\end{tabular}

There are three traits that should not be owned by educational leaders according to the perception of 112 students $(98.25 \%)$ are: fanatics, promises a sale, and arrogant. Next, there is one trait that should not be owned by the leader of education according to the perception of 111 students $(97.37 \%)$ are: angry.
Results Analysis of Properties Or Character Education Leaders Most Liked According to Student Perceptions

Description of data analysis results about the characteristics or characteristics of the most preferred educational leaders according to student perceptions is depicted in Table 3.

Table 3

Characteristics or Character of the Most Preferred Education Leader According to Student Perceptions

\begin{tabular}{clcc}
\hline No & Characteristics or Character Education Leaders Most Preferred & $\begin{array}{c}\text { Number of Respondents } \\
(\%)\end{array}$ & $\begin{array}{c}\text { Percentage } \\
(\%)\end{array}$ \\
\hline 1 & Responsible & 114 & 114 \\
2 & Wise & 114 & 100 \\
3 & Honest & 114 & 100 \\
4 & Discipline & 114 & 100 \\
5 & Commitments & 114 & 100 \\
6 & Having caring & 114 & 100 \\
7 & Human & 114 & 100 \\
8 & Able to solve the problem & 114 & 100 \\
9 & Consistent (aligned between speech and deeds) & 114 \\
10 & Creative. & 100 \\
\hline
\end{tabular}

Table 4

Characteristics or Character of the Most Outstanding Educational Leader Preferred According to Student Perceptions

\begin{tabular}{|c|c|c|c|}
\hline No & $\begin{array}{c}\text { Sifat-Sifat atau Karakter Pemimpin Pendidikan yang } \\
\text { Paling Tidak Disukai }\end{array}$ & $\begin{array}{c}\text { Jumlah } \\
\text { Responden }\end{array}$ & Persentase $(\%)$ \\
\hline 1 & Amusing (arrogant) & 114 & 100 \\
\hline 2 & Indifferent (ignorance) & 114 & 100 \\
\hline 3 & Likes to ramble (ramble) & 114 & 100 \\
\hline 4 & Discriminatory (favoritism) & 114 & 100 \\
\hline 5 & Selfish (self-centered) & 114 & 100 \\
\hline 6 & Corruption & 114 & 100 \\
\hline 7 & Less commitment & 114 & 100 \\
\hline 8 & less flexible & 114 & 100 \\
\hline 9 & Slow in making decisions & 114 & 100 \\
\hline 10 & Lazy & 114 & 100 \\
\hline 11 & Coward & 114 & 100 \\
\hline 12 & Fearful & 114 & 100 \\
\hline 13 & Pretentious & 114 & 100 \\
\hline 14 & Likes to procrastinate work & 114 & 100 \\
\hline 15 & Closed & 114 & 100 \\
\hline 16 & Not populated & 114 & 100 \\
\hline 17 & Haste (rash) & 114 & 100 \\
\hline 18 & Not accountable & 114 & 100 \\
\hline 19 & Not Innovative & 114 & 100 \\
\hline 20 & No discipline & 114 & 100 \\
\hline 21 & Inconsistent & 114 & 100 \\
\hline 22 & Not creative & 114 & 100 \\
\hline 23 & Likes & 114 & 100 \\
\hline
\end{tabular}

Based on Table 3 it can be explained that there are ten characteristics and characters of the most preferred educational leaders according to the students' perceptions. In this case, the ten properties are selected by all respondents (114 students) or $100 \%$ of respondents. The most 
preferred characteristics or characteristics of educational leaders include responsible, wise, honest, disciplined, committed, caring, humane, able to solve problems, consistent (aligned between speech and action), and creative.

\section{Results of Analysis of Nature-Character or Character Education Leader of the Most Disliked}

Descriptions of data on the analysis of the characteristics or characteristics of educational leaders most disliked according to student perceptions are illustrated in Table 4.

Based on Table 4 it can be explained that there are twenty-three characteristics and characteristics of educational leaders that are least favored according to student perceptions. In this case, 23 properties were selected by all respondents (114 students) or $100 \%$ of respondents. The most disliked characteristics or character of educational leaders include: arrogant, indifferent, verbose, lying, discriminatory, selfish, corruption, lack of commitment, rigid, slow in making decisions, lazy, Cowardly, cowardly, pretentious, procrastinating, closed, unpopulated, rash, irresponsible, unlovable, undisciplined, inconsistent, not creative and lying.

\section{DISCUSSION}

Results of Analysis of Properties or Characteristics that Educative Leaders Should Have According to Student Perceptions

As presented in the research results, this study found there are sixty (60) characteristics or character of educational leaders that should be owned by educational leaders according to student perceptions. The qualities of the educational leader include: responsible, wise, honest, disciplined, committed, caring, humane, able to solve problems, one word-one deed, and creative, have emotional stability, enthusiasm, openness to criticism, and innovative, fair , Inspirational, exemplary, hospitality, assertiveness, nurturing attitude, personal integrity, confidence, intelligence and problem solving, cooperative, openness, firmness, patience, adaptability, respect for the opinions of others, and able to communicate Oral, confidence, diligence, humility, priority of the interests of others (group), and able to make the right decision, have initiative, breadth of view, maturity, confidence, morality, and helpful, have a social or friend, simple, And able to maintain interpersonal relationships, charismatic, devotion, flexibility, and achievement motivation, humorist, understand Himself, able to communicate in writing, and has physical fitness, sincerity, excellent health, teaching skills, has a broad educational perspective, has technical expertise in education. Has a good (good dress) appearance, cute (beautiful and handsome).

In general, the results of this study have similarities and differences with the results of previous studies. Stogdill [5] suggests that from 15 observations found there are 5 kinds of characteristics that should be owned by leaders, namely: intelligence, scholarship, dependability in exercising responsibilities, activity and social participation, and socioeconomic status. Then based on more than 10 subsequent observational studies it was proposed that a leader should have the following characteristics: sociability, initiative, persistence, knowing how to get done, self-confidence, alertness to and insight into the situation, cooperativeness, popularity, adaptability, and Verbal facility.

\section{Results of Analysis of Properties Or Character Should Not Be Owned by Educational Leaders According to Student Perceptions}

The results of this study indicate that there are 30 traits or characters that should not have educational leaders. The qualities that the education leader should not have are: arrogant, indifferent, verbose, lying, discriminatory, selfish, corrupt, lacking commitment, rigid, slow in making decisions, lazy, cowardly, timid, Pretentious, procrastinating, closed-minded, unpopular, hasty, irresponsible, unsolvable, undisciplined, inconsistent, uninvolved, dexterous, stingy, arrogant, fanatic, promised sale, And grumpy.

It seems that the results of this study do not differ much from previous research, as expressed by Freeman and Taylor (1982) that there are 13 qualities that should be owned by the leader, namely: lazy, stubborn, error-free, shy, cowardly, non-retreating, More emotionless, unreasonable, helpless, bored, and fanatical. The number of similarities between the results of this study and the results of previous research may be due to the nature of the "less good" leader is almost happening in all areas of the institution. In other words, the qualities of these leaders are universal and tend to exist in all types of institutions including education institutions. Even if it is a bit different that is caused by trending issues in our country this is a lot of corruption in every field. Therefore, the nature of corruption is a trait that should not be owned by leaders, especially leaders in educational institutions.

\section{Results Analysis of Properties Or Character Education Leaders Most Liked According to Student Perceptions}

The characteristics or character of the most preferred educational leaders based on the results of this study there are 10 traits or characters. These traits include responsible, wise, honest, disciplined, committed, caring, humane, able to solve problems, be consistent (between speech and action), and creative.

The results of previous research proposed by Stogdil in [5] that there are 10 qualities that are preferred and must be owned by leaders are: sociability, initiative, persistence, knowing how to get done done, self confidence, alertness to and insight into situation, cooperativeness, popularity, Adaptability, and verbal facility. If the results of this Stogdil observation are compared with the results of this study it appears very different but can be viewed complementary.

These differences may be due to differences in the timing of the study, but may also be attributed to different institutions. In this case, Stogdil's observations are conducted in non-educational 
institutions, whereas the research is conducted at higher education institutions so it is natural that there are different specific matters that characterize the favored leader's characteristics.

\section{Results of Analysis of Nature-Character or Character Education Leader of the Most Disliked}

There are twenty-three (23) characteristics or characteristics of educational leaders that are least favored (according to student perceptions) produced by this study. These properties include: arrogant, indifferent, discriminatory, selfish, corruption, lack of commitment, stiffness (lack of flexibility), Slow in making decisions, lazy, cowardly, cowardly, pretentious, Like procrastinating, closed, not populist, hasty, irresponsible, non-innovative, undisciplined, inconsistent, not creative Likes to lie.

In this case, Sank in [5] also states that there are traits that are often characterized by ineffective leaders, that is, uncooperative, bad communicators, poor decision-making processes, lack of leadership, non-communicative, centered on Self, not aggressive, and not a delegator. It seems that Sank's opinion is very different from the results of this study. This difference may be due to differences in the time this study was conducted. Sank's opinion was put forward in 1982 and the study was conducted in 2016. This time difference in implementation certainly had an impact on different research results because, in addition to the different situations and issues, the trending issues were also different.

\section{Conclusion}

\section{CONCLUSIONS AND RECOMMENDATIONS}

There are ten characteristics or characters of the most preferred educational leaders according to the students' perceptions. The characteristics of the educational leader can be classified according to their character as follows: 1) Personality character, including responsible, wise, honest, disciplined, and consistent (aligned between speech and deed); 2) Social character, including having caring, commitment, and humane; And 3) intellectual character, including able to solve problems, and creative.

There are 23 characteristics or characteristics of educational leaders are the most disliked according to student perceptions. The characteristics of the educational leader can be classified according to their character as follows: 1) Personality traits include: arrogant, indifferent, corrupt, rigid (less flexible), lazy, Cowards, cowards, pretentious, closed, hasty, irresponsible, undisciplined, inconsistent, and lying; 2) Social Character, including: discriminatory (favoritism), lack of commitment, and selfish (selfish); And 3) Intellectual character, including: slow in making decisions, likes to procrastinate, not innovative, not populist, and not creative.

Suggestion

Based on the conclusion, then can be put forward suggestions as follows. For education leaders, especially educational leaders in universities, it is necessary to adjust their leadership traits or characteristics to the dynamics that occur among students, as well as the trends of issues that develop in society. For the Department of Education Administration FIP UM, that the results of this study can be used as a reference to develop the subject matter of leadership and other relevant subjects. For future research, it is hoped that the results of the research can provide inspiration to conduct similar research with different approach and more different area coverage.

\section{REFERENCES}

[1] Arikunto, S. 2010. Prosedur Penelitian: Suatu Pendekatan Praktik (Edisi Revisi VI). Yogyakarta: Rineka Cipta.

[2] Davis, G.A., \& Thomas, M.A. 1989. Effective Schools and Effective Teachers. Boston: Allyn and Bacon.

[3] Freeman, G.L. \& Taylor, E.K. 1982. How to Pick Leader, A Scientific Approach to Executive Selection. New York: Funk \&Wagnall Company.

[4] Gorton, R.A., \& Schneider, G.T. 1991. Schools-Based Leadership: Challenges and Opportunities. Dubuque, Iowa: Wim C. Brown Company Publisher.

[5] Mitchell, T.R. 1984. People in Organization An Introduction to Organization Behavior. New Delhi: McGraw-Hill International Book Company.

[6] Sergiovanni, T.J. 1991. The Principalship: A Reflective Practice Perspective. Boston: Allyn and Bacon.

[7] Thierauf, R.J.; Klekamp, R.C.; and Geeding, D.W. 1977. Management Principles and Practices A Contingency and Questionnaire Approach. New York: John Willy and Sons.

[8] Wiyono, B, B. 2007. Metode Penelitian (Pendekatan Kuantitatif, Kualitatif, dan Action Research. Malang: Universitas Negeri Malang.

[9] Yukl, G. 2010. Kepemimpinan dalam Organisasi. Jakarta: PT. Indeks. 